\title{
New data on Aituaria pontica (Spassky, 1932) (Aranei: Nesticidae)
}

\author{
Новые данные о Aituaria pontica (Spassky, 1932) \\ (Aranei: Nesticidae)
}

\author{
Sergei L. Esyunin \\ С. $\Lambda$. Есюнин
}

Perm State University, Bukireva Street 15, Perm, Russia, 614600. E-mail: Sergei.Esyunin@psu.ru

Пермский государственный университет, ул. Букирева 15, Пермь 614600 Россия.

KEY WORDS: cave cobweb spiders, Aituaria, distribution, new synonym.

КЛЮЧЕВЫЕ СЛОВА: пауки нестициды, Aituaria, распространение, новый синоним.

ABSTRACT. The genus Aituaria Esyunin et Efimik, 1998 is redefined as monotypic. It is close to the predominantly Caucasian borutzkyi species group of the genus Carpathonesticus Lehtinen et Saaristo, 1980, but can easily be distinguished from it by the broad, ribbon-shaped embolus notched at its tip, as compared to the narrow, tapering off embolus in the borutzkyi species group. The species Aituaria nataliae Esyunin et Efimik, 1998 is synonymized with A. pontica (Spassky, 1932). A. pontica is reported from the Middle Urals for the first time, its male palp is illustrated and distributional and ecological data are also summarized.

РЕЗЮМЕ. Род Aituaria Esyunin et Efimik, 1998 признан монотипическим. Он близок к преимущественно кавказской группе видов borutzkyi рода Carpathonesticus Lehtinen et Saaristo, 1980, но хорошо отличается от нее широким лентообразным с выемкой на вершине эмболюсом, в сравнении с узким суженным к вершине эмболюсом у группы видов borutzkyi. Вид Aituaria nataliae Esyunin et Efimik, 1998 синонимизирован с $A$. pontica (Spassky, 1932). A. pontica впервые указывается для Среднего Урала, пальп самца проиллюстрирован, а также обобщены данные о распространении и экологии вида.

\section{Introduction}

The spider genus Aituaria Esyunin et Efimik, 1998, with the type species A. nataliae Esyunin et Efimik, 1998, was described by Esyunin and Efimik [1998] on the basis of a single male collected from the southern Urals. The second species of the genus, A. pontica (Spassky, 1932) from Krasnodar Province and the Caucasian coast of Black Sea was transferred by the same authors from the genus Nesticus Thorell, 1869. Thus, currently the genus Aituaria consists of two species [WSC, 2017].
Recently, additional Aituaria specimens have been collected from the City of Perm (Russia). Having examined them, the author has come to the conclusion that $A$. nataliae and $A$. pontica are to be considered conspecific. The main aims of this paper are (1) to synonymize both species names, (2) to illustrate important diagnostic characteristics of the male palp, and (3) to provide new distributional and ecological data for A. pontica.

\section{Material and methods}

SEM micrographs were made by means of a Hitachi TM3000 SEM microscope with BSE (back-scattered electrons) at the Perm State University.

The material treated in the present paper is deposited in the collections of the Zoological Museum of the Perm State University (PSU, curator: S.L. Esyunin).

The terminology of the nesticid palp follows Lopez-Pancorbo, Ribera [2011] and Pavlek, Ribera [2017].

\section{Systematic part}

Genus Aituaria Esyunin et Efimik, 1998

TYPE SPECIES. Nesticus ponticus Spassky, 1932; as the senior synonym of Aituaria nataliae Esyunin et Efimik, 1998.

DIAGNOSIS. The genus Aituaria is close to the borutzkyi species group of the genus Carpathonesticus Lehtinen et Saaristo, 1980, of which five species are distributed in the Caucasus and the Ciscaucasia Region, viz.: C. birsteini (Charitonov, 1947), C. borutzkyi (Reimoser, 1930), C. caucasicus (Charitonov, 1947) and C. zaitzevi (Charitonov, 1939), as well as C. ljovuschkini (Pichka, 1965) which is known from the female but yet suits the diagnosis of the borutzkyi species group by Lehtinen, Saaristo [1980]. In my opinion, two other species from Georgia - C. mamajevae Marusik, 1987 and C. eriashvilii Marusik, 1987 - 

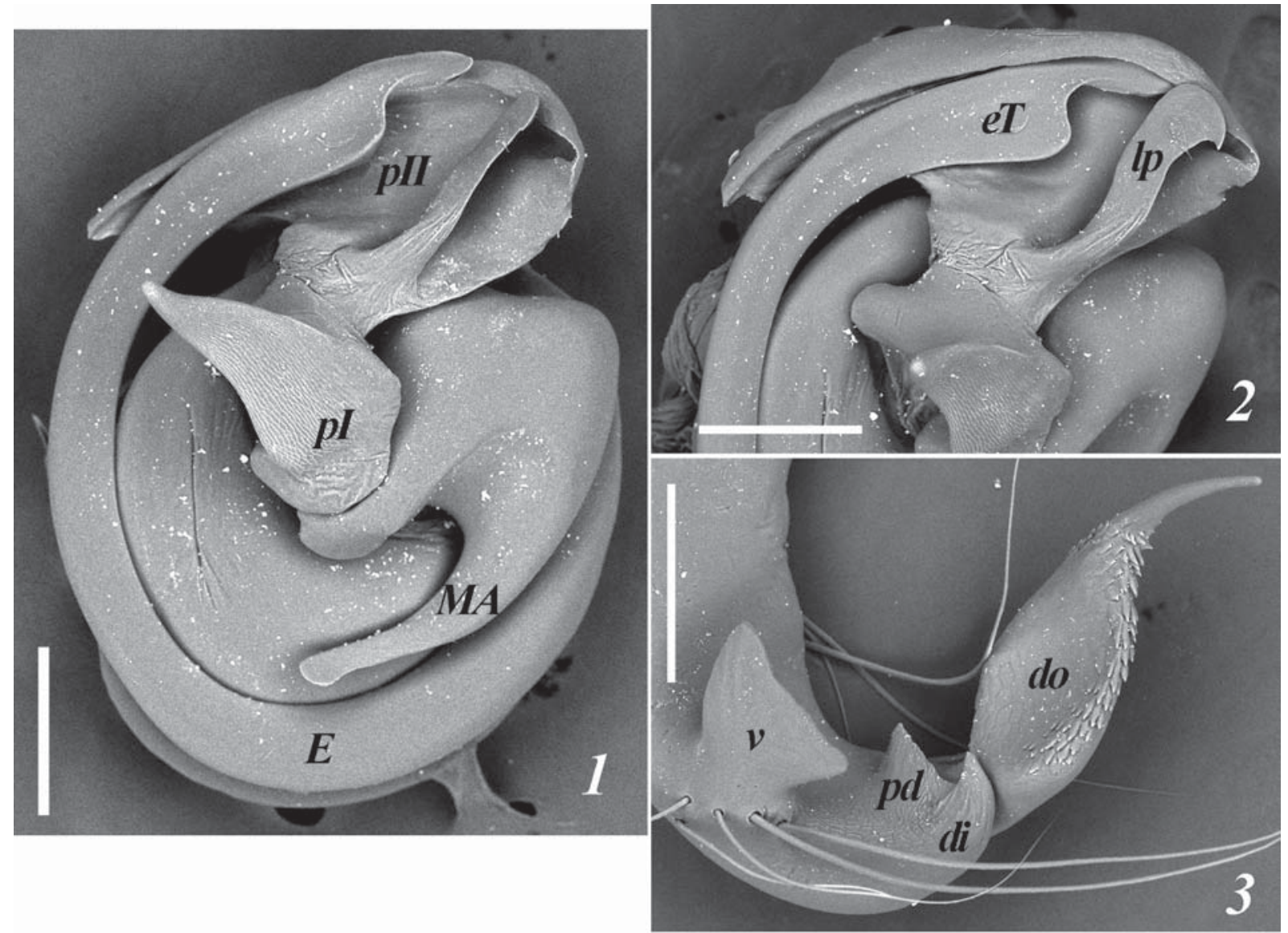

Figs 1-3. Diagnostic characters of the male palp of Aituaria pontica (Spassky, 1932): 1 - bulbus, 2 - process II of the theridioid tegular apophysis and embolic tip, 3 - paracymbium tip, all ventral views. Abbreviations: di - distal process; do — dorsal process; $E$ embolus; $e T$ - embolic tip; $l p$ - lamellar process of the process II; $M A$ - median apophysis; $p I$ and $p I I$ - process I and II of the theridioid tegular apophysis, respectively; $p d$ - paradistal process; $v$ - ventral process. Scale $0.2 \mathrm{~mm}$.

Рис. 1-3. Диагностические признаки пальпа самца Aituaria pontica (Spassky, 1932): 1 - бульбус, 2 - отросток II теридиидной тегулярной апофизы и вершина эмболюса, 3 - вершина парацимбиума, все вид снизу. Аббревиатура: $d i$ - дистальный отросток; $d o$ - дорсальный отросток; $E$ - эмболюс; $e T$ - вершина эмболюса; $l p$ - пластинчатый отросток $p I I ; M A-$ срединная апофиза; $p I$ и $p I I$ - отростки I и II теридиидной тегулярной апофизы, соотвественно; $p d$ - парадистальный отросток; $v$ - вентральный отросток. Масштаб 0,2 мм.

have little in common with true members of the borutzkyi species group and seem to compose a separate species group. The common characteristics of the male palp both in Aituaria and in the aforementioned species of the borutzkyi species group are as follow: (1) the paracymbium with dorsal, ventral and paradistal processes, but without the "barbed part" [Lehtinen, Saaristo, 1980]; (2) the protruding process 1 of the theridioid tegular apophysis more or less triangular in shape; (3) the process 2 of the theridioid tegular apophysis with a narrow lamellar process; and (4) the trapezoid median septum of the epigyne. However, $A$. pontica differs from all species of the borutzkyi group in having (1) the broad ribbon-like embolus notched at its tip (Figs 1-2), as compared to the narrow, tapering off embolus in that species group [Charitonov, 1941: Fig. 1, 3; Wiehle, 1963: Fig. 5-6: Pichka, 1965: Fig. 2a; Marusik, 1987: Fig. 1; Nadolny, Kovblyuk, 2007: Fig. 2] and (2) the distal process of the paracymbium
(Fig. 3), which is absent from the species of the borutzkyi species group. 147].

DESCRIPTION. See Esyunin and Efimik [1998: COMPOSITION. Aituaria pontica (Spassky, 1932).

Aituaria pontica (Spassky, 1932) Figs 1-3.

Nesticus ponticus Spassky, 1932: 975, Figs 1-8 ( $\left.\sigma^{7}+\right)$. Nesticus ponticus: Charitonov, 1947: 19, Figs 3-5 (O'O). Carpathonesticus ponticus: Mikhailov, 1996: 80 (from Nesticus).

Nesticus ponticus: Mcheidze, 1997: 293, Figs 678-680 (○'o). Aituaria pontica: Esyunin, Efimik, 1998: 147, Fig. 3 (†; from Carpathonesticus).

Aituaria natali Esyunin, Efimik, 1998: 147, Figs 1-2, 4-7 $\left(O^{\top}+\right)$. Syn.n.

MATERIAL. 1 ○', 2 우, 1 juvenile (PSU-6389), City of Perm, sewage header, 17.01.2013, N.N. Pan'kov. For other materials studied see in Esyunin, Efimik [1998]. 
DESCRIPTION. See Esyunin, Efimik [1998: 147; sub $A$. pontica and $A$. natali].

DISTRIBUTION. The Crimea: Sevastopol, $44^{\circ}$ $36^{\prime} \mathrm{N}, 33^{\circ} 32^{\prime} \mathrm{E}$ [Nadolny, Turbanov, 2014; Kovblyuk, Kastrygina, 2015]. Krasnodar Province: Sochi, 433 $31^{\prime} \mathrm{N}$, 39॰52'E, Verkhne-Mzymtinskaya cave (Mzymta Riv-

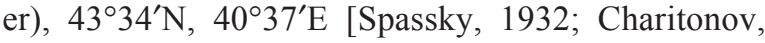
1947; Pichka, 1965; Mcheidze, 1997; Esyunin, Efimik, 1998]. Orenburg Area: Aituar [Esyunin, Efimik, 1998]. Perm Province: Perm [present data]. Eastern Ukraine: Chernivtsi [Marusik, pers. comm.]. The record of $A$. pontica from Tarkiladze Cave (Duripsh, Abkazia), $43^{\circ} 12^{\prime} \mathrm{N}, 40^{\circ} 38^{\prime} \mathrm{E}$ [Charitonov, 1947: 19] seems to belong to another species, as the latter author noted that the female deviated "significantly from the typical form".

ECOLOGY [Spassky, 1932; Pichka, 1965; Mcheidze, 1997; Esyunin, Efimik, 1998; Nadolny, Turbanov, 2014]. In the Crimea and Krasnodar Province, A. pontica dwells both in natural caves, and in similar anthropogenic habitats (wine cellars, mines, etc.); in the Urals (Orenburg Region, Perm City), it is a synanthropic species. In Perm Area, where the cave fauna has been specially explored [e.g., Pan'kov et al., 2009], the species was not found in natural caves. Phenology: $\sigma^{T} \sigma^{T}$ - IX-III, $+\varnothing-$ VII-III, juveniles - VII-III.

ACKNOWLEDGMENTS. The author is grateful to the Head of Zoological Museum of the Perm State University, A.V. Grischenko, for allowing him to use Museum's SEM facilities and to Yuri M. Marusik (Magadan, Russia) for commenting on the manuscript and providing distributional information. Special thanks go to Dmitri V. Logunov (Manchester, UK) for commenting on the manuscript and editing the English of the final draft.

\section{References}

Charitonov D.E. 1947. [Spiders and harvest spiders from the caves of the Black Sea coast of the Caucasus] // Byulleten' Moskovskogo Obshchestva Ispytatelei Prirody. Vol.52. P.15-28 [in Russian].

Esyunin S.L., Efimik V.E. 1998. Remarks on the Ural spider fauna, 8. New and unidentified species from steppe landscapes of the South Urals (Arachnida: Aranei) // Arthropoda Selecta. Vol.7. No.2. P.145-152.

Kovblyuk M.M., Kastrygina Z.A. 2015. [Updated catalogue of the spiders (Arachnida, Aranei) of the Crimea] // Ukrainska Entomofaunistika. Vol.6. No.2. P.1-81 [in Russian].

López-Pancorbo A., Ribera C. 2011. Nesticus baeticus sp. n., a new troglobitic spider species from south-west Europe (Araneae, Nesticidae) // ZooKeys. Vol.89. P.1-13.

Mcheidze T.S. 1997. [Spiders of Georgia: Systematics, Ecology, Zoogeographic Review]. Tbilisi: Tbilisi Univ. Press. 390 p. [in Georgian]

Mikhailov K.G. 1996. A checklist of the spiders of Russia and other territories of the former USSR // Arthropoda Selecta. Vol.5, No.1/2. P.75-137.

Nadolny A.A., Turbanov I.S. 2014. The first record of Aituaria pontica (Aranei, Nesticidae) in the Crimea // Vestnik zoologii. Vol.48. No.6. P.569.

Pan'kov N.N., Starova O.S., Pan'kova N.V. 2009. [The invertebrate animals of the cave of the Perm Province: fauna, ecological structure, chorology and seasonal dynamics] // Peschery (Caves). No.32. P.72-83 [in Russian].

Pavlek M., Ribera C. 2017. Kryptonesticus deelemanae gen. et sp. nov. (Araneae, Nesticidae), with notes on the Mediterranean cave species // European Journal of Taxonomy. Vol.262. P.127.

Pichka V.E. 1965. [On the spider fauna of the caves in the west Transcaucasia] // Zoologicheskiy Zhurnal. Vol.44. No.8. P.1190-1196 [in Russian].

Spassky S.A. 1932. Aranearum species novae, II // Bulletin du Muséum National d'Histoire Naturelle de Paris. Ser.2. Vol.4. P.972-979.

WSC. 2017. World Spider Catalog. Version 18.0. Natural History Museum Bern. Available at http://wsc.nmbe.ch (accessed 10 May 2017). 